\title{
INFLUENCE OF CONSTRUCTION'S LOADING LEVEL ON STRENGTH AND DEFORMABILITY OF RC COLUMNS STRENGTHENED BY CFRP
}

\begin{abstract}
This paper presents results of research of reinforced concrete columns strengthened by CFRP laminate under different load levels. During the building exploitation it is often difficult to completely unload the structure, and in some cases impossible. To simulate this factor before strengthening experimental samples were adjusted to the level of $1 / 3$ and $1 / 2$ of experimentally determined destructive efforts of the unstrengthened column. For more experimental research dates two columns were strengthened without loading. All samples were strengthened by CFRP laminate Sika Carbodur S512 with $25 \mathrm{~mm}$ width. The loading was applied with eccentricity $e=150 \mathrm{~mm}$. Comparative analysis was carried out and strengthened effectiveness was determined. The effectiveness of strengthening increases with decreasing loading level on construction but this difference was small during testing.
\end{abstract}

Keywords: reinforced columns, strengthening, CFRP laminate

\section{Introduction}

One of the most popular in today's world materials for construction of buildings is reinforced material which combines steel and concrete. Concrete protects the steel from corrosion and with steel perceives compression and stretch forces. Under the influence of time, the negative impact of the environment, not quality materials its performance properties deteriorate and, consequently, the carrying capacity is reduced. Therefore the need appears to restore or strengthen these structures. One of modern methods of strengthening is the use of carbon-fiber-reinforced polymers (CFRP) $[8,10,12,13,17,18,20$,

\footnotetext{
${ }^{1}$ Autor do korespondencji/corresponding author: Roman Khmil, Lviv Polytechnic National University, blv. St. Bandery 12, 79013 Lviv, Ukraine, roman_hl@ukr.net

${ }^{2}$ Yaroslav Blikharskyy, Lviv Polytechnic National University, yzb@ukr.net

${ }^{3}$ Igor Vasiliev, Lviv Polytechnic National University, bslavko@ukr.net
} 
22]. The advantage is their great corrosion resistance to environmental factors, high stiffness and strength and weight in comparison with other materials.

Disadvantage of relatively high cost is offset by cost reduction and labor when performing work on strengthening, by decrease of performance time, by lack of needs to use the expensive equipment, installed and used without unloading the structures.

\section{Reference analysis}

Currently, for FRP strengthening systems there are designed code and guidelines in many countries, such as in the U.S.A [1, 2], Canada [18], EU [6, 13], Italy [7], Germany [5], UK [21, 22], Switzerland [16], France [14], Japan $[9,11,12]$, China [19]. There are many research works in the world $[4,8,10,15$, $20,23]$ and also in Ukraine this question is studied by researchers [3, 9].

\section{Goal and objectives}

The goal of this work is to determine the parameters of strength of reinforced concrete columns strengthened by CFRP laminate at different levels of initial load, comparing them with unstrengthened columns, setting efficiency of strengthened ones.

\section{Methods of experimental research}

To achieve the goal the experimental samples of columns with dimensions $2200 \times 180 \times 140 \mathrm{~mm}$ were made. At the edges of columns cantilever was constructed to apply the eccentrically load. In the research the accepted eccentricity equals to $150 \mathrm{~mm}$. The construction of experimental samples is shown in fig. 1.

During the production process special fasteners were attached to reinforing bars. They serve for attaching mechanical devices to determine the deformation of steel reinforcement. To simulate the real exploitation conditions of rc columns the specimens before strengthening were loaded to the level of $0.3 N_{u}^{\exp }$, $0.5 N_{u}^{\exp }(1 / 3$ and $1 / 2$ of experimentally determined destructive forces of unstrengthened samples). For comparison two columns also were strengthened without loading. Then samples were strengthened by CFRP laminate Sika Carbodur S512 (fig. 2). Laminate width was $25 \mathrm{~mm}$.

CFRP laminate was attached to the stretched edge of the column. For reliable laminate anchoring two layers of fabric SikaWrap were applied on the cantilever. Work was performed by the manufacturer technique [17]. 


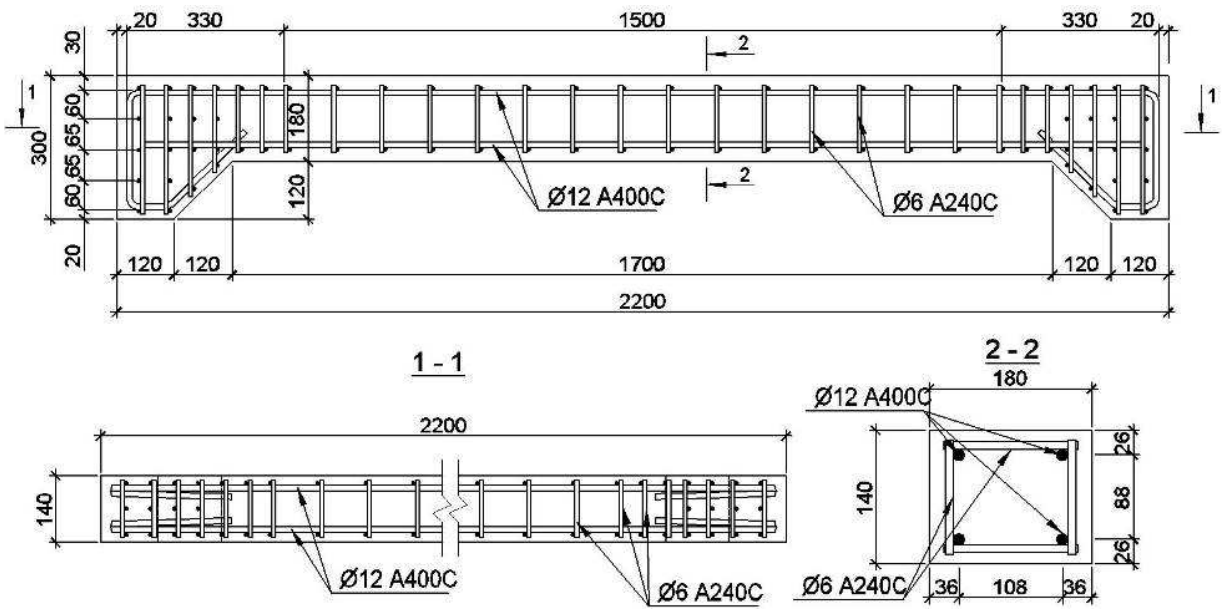

Fig. 1. Design and reinforcement of unstrengthened samples

Rys. 1. Projekt i zbrojenie próbek niewzmocnionych

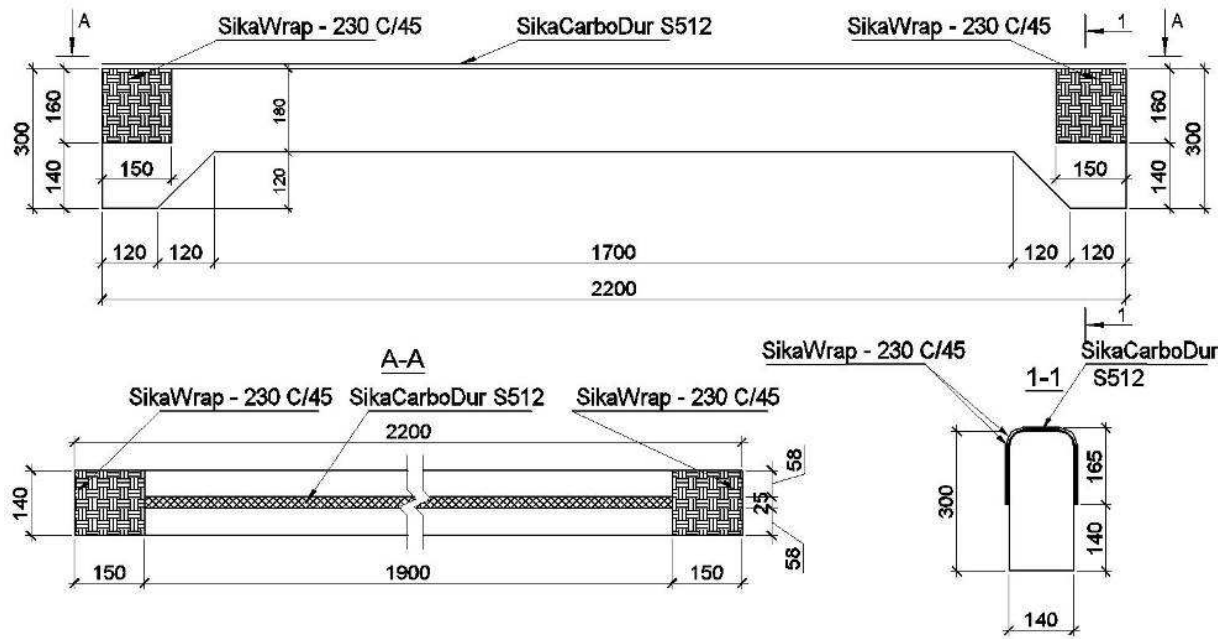

Fig. 2. Reinforcement of samples strengthened by CFRP laminate

Rys. 2. Zbrojenie próbek wzmocnionych taśmami CFRP

The following labeling for experimental samples was chosen: $\mathrm{CU}$ - column unstrengthened, CSL - column strengthened by CFRP laminate. The first number in column label indicates the batch number, the second one - number of column in the series and the number that stands after the dash indicates - the loading level during strengthening. During the experimental studies 8 samples were tested, namely two unstrengthened columns (CU-0.1 and CU-0.2), two columns (CSL-1.3 and CSL-1.4) were strengthened without loading, two 
samples (CSL-1.5-0,3 and CSL-1.6-0,3) were strengthened under loading equal to 0.3 from strength capacity of samples CU-0.1 and CU-0.2 and two samples (CSL-1.7-0.5 and CSL-1.8-0.5) were strengthened under 0.5 from strength of unstrengthened columns.

Strengthened samples were tested to failure. Loading was applied in steps $10 \mathrm{kN}$ each with $15 \mathrm{~min}$ between steps. The load was applied by the hydraulic jack. Experimental samples were tested in the horizontal position. To determine the deformation characteristics of columns generally 28 strain gauges were used during not strengthened columns test and 35 strain gauges during strengthened columns test. There by the gauges the strain of reinforcement and concrete was measured. To measure the curvature of the columns 5 deflectometers were placed along its length (fig. 3).
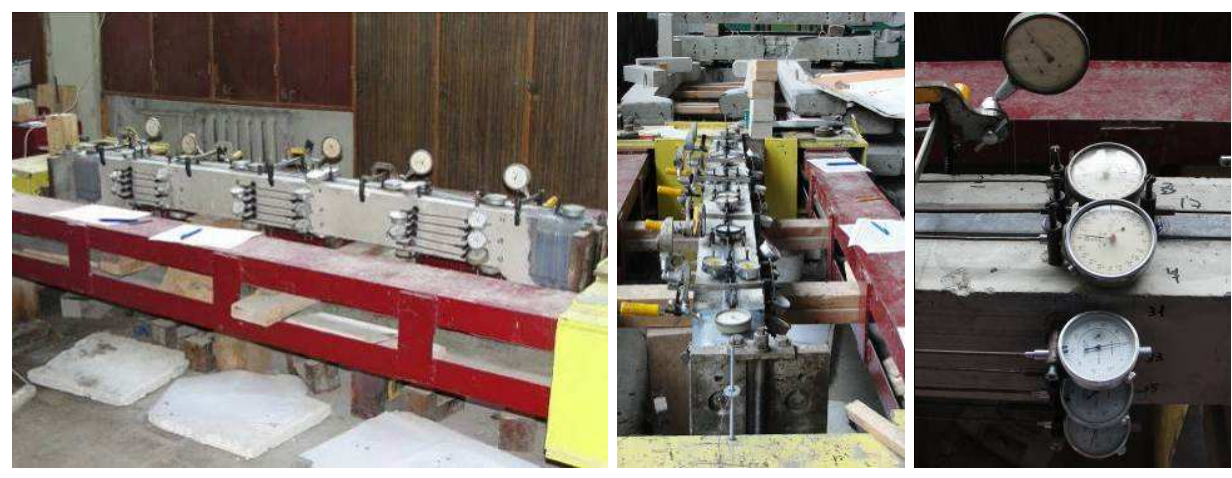

Fig. 3. Sample CSL-1.8-0.5 during test

Rys. 3. Próbka CSL-1.8-0.5 podczas badań

\section{Results and discussion}

In all experimental samples three cross-sections were considered. In each cross-section two gauges were placed on stretched reinforced bars and one gauge on concrete of compressed edge of the column. On the additional reinforcement gauges were placed along the length of the laminate.

According to recommendation of FIB [6] there are 2 limit states. The first is „serviceability limit state (SLS)”, and the second - „ultimate limit state (ULS)”. SLS corresponds to the moment when the strain in the stretched steel bars and CFRP laminate reaches the limit values. However, if the deformation of steel reinforcement reached the yield stress and strain of CFRP laminate have not reached the limit values, and vice versa, is considered that the SLS has not been reached. ULS corresponds to the moment when compressed concrete of crosssection is crushed.

Using obtained experimental results we plotted the averaged graphics of deformations of compressed concrete, stretched steel bars and CFRP laminate in 
depending from loading for all columns (fig. 4). Yielding of steel reinforcement begins at $\varepsilon_{S a}=280 \cdot 10^{-5}$ (Young's modulus $E=205 \mathrm{GPa}$ ). Limit state for CFRP laminate was determined at $\varepsilon_{S L}=500 \cdot 10^{-5}$ (Young's modulus $165 \mathrm{GPa}$ ) according to FIB [6].

a)

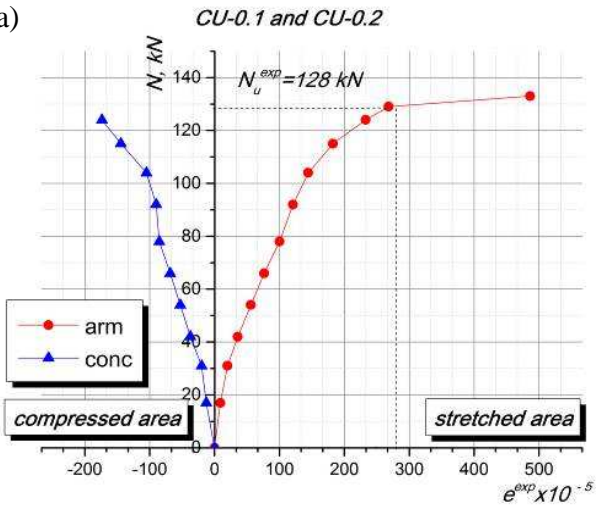

c)

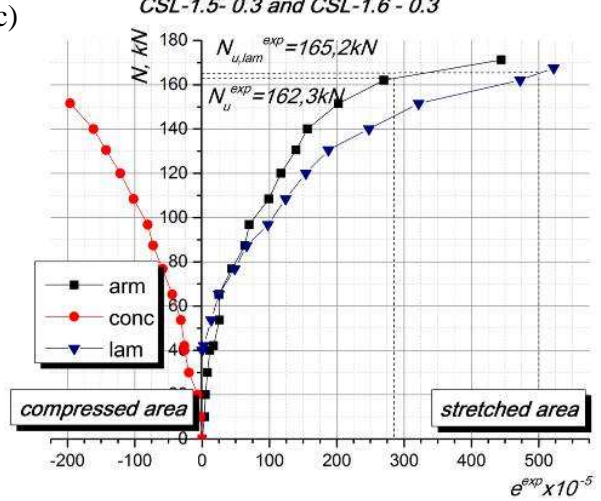

b)

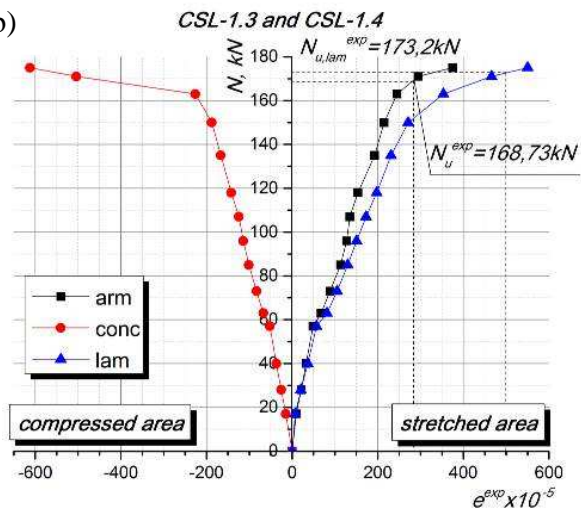

d)

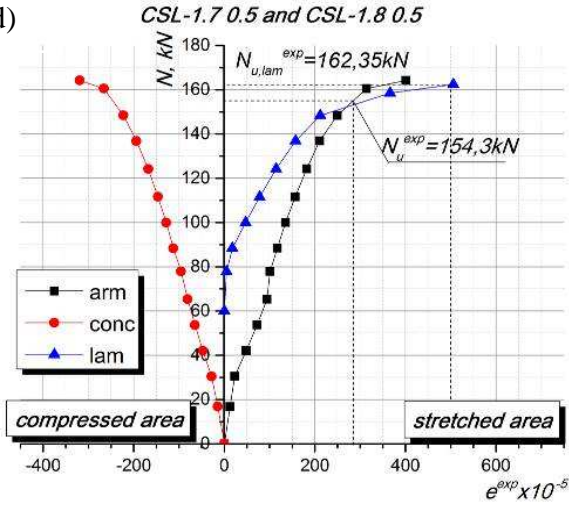

Fig. 4. Strain in stretched reinforcement (arm) and laminate (lam), compressed concrete (bet) of columns: a) CU-0.1 and CU-0.2, b) CSL-1.3 and CSL-1.4, c) CSL-1.5-0.3 and CSL-1.6-0.3, d) CSL-1.7-0.5 and CSL-1.8-0.5; average of twins

Rys. 4. Odkształcenia w zbrojeniu rozciąganym (arm) i taśmie z włókien węglowych (lam) oraz betonie ściskanym (bet) słupów: a) CU-0.1 I CU-0.2, b) CSL-1.3 i CSL-1.4, c) CSL-1.5-0.3 i CSL-1.6-0.3, d) CSL-1.7-0.5 i CSL-1.8-0.5; wartość średnia z dwóch

After analyzing we compare the value of the compressive force at which the limit state of each components of samples (steel reinforcement, CFRP laminate, concrete) occurs (tab. 1-3).

Strengthening effect for samples CSL-1.3 and CSL-1.4 was 31.8\%, for samples CSL-1.5-0.3 and CSL-1.6-0.3 - 26.8\% and for samples CSL-1.7-0.5 and CSL-1.8-0.5 - 20.5\%. 
Table 1. Compressive force at reinforcement yield state

Tabela 1. Siła ściskająca w chwili uplastycznienia zbrojenia

\begin{tabular}{|c|c|c|c|c|c|}
\hline \multirow[t]{2}{*}{ Sample } & \multirow{2}{*}{$\begin{array}{c}\text { Cross-section } \\
\text { dimensions, } \\
b \times h \text { [mm] }\end{array}$} & \multicolumn{2}{|c|}{$\begin{array}{l}\text { Compressive force at } \\
\text { reinforcement yield [kN] }\end{array}$} & \multicolumn{2}{|c|}{$\begin{array}{c}\text { Strengthening } \\
\text { effect [\%] }\end{array}$} \\
\hline & & sample & average & sample & average \\
\hline CU-0.1 & \multirow{8}{*}{$140 \times 180$} & 127.4 & \multirow{2}{*}{128} & - & \multirow{2}{*}{-} \\
\hline CU-0.2 & & 128.6 & & - & \\
\hline CSL-1.3 & & 168.4 & \multirow{2}{*}{168.73} & 31.6 & \multirow{2}{*}{31.8} \\
\hline CSL-1.4 & & 169.05 & & 32.1 & \\
\hline CSL-1.5-0.3 & & 163.2 & \multirow{2}{*}{162.3} & 27.5 & \multirow{2}{*}{26.8} \\
\hline CSL-1.6-0.3 & & 161.4 & & 26.1 & \\
\hline CSL-1.7-0.5 & & 153.5 & \multirow{2}{*}{154.3} & 19.9 & \multirow{2}{*}{20.5} \\
\hline CSL-1.8-0.5 & & 155.1 & & 21.2 & \\
\hline
\end{tabular}

Table 2. Compressive force at CFRP laminate limit state

Tabela 2. Siła ściskająca w chwili osiągnięcia nośności przez taśmę CFRP

\begin{tabular}{|c|c|c|c|c|c|}
\hline \multirow[t]{2}{*}{ Sample } & \multirow{2}{*}{$\begin{array}{c}\text { Cross-section } \\
\text { dimensions } \\
b \times h[\mathrm{~mm}]\end{array}$} & \multicolumn{2}{|c|}{$\begin{array}{l}\text { Compressive force at SLS } \\
\text { of CFRP laminate }[\mathrm{kN}]\end{array}$} & \multicolumn{2}{|c|}{$\begin{array}{l}\text { Strengthening } \\
\text { effect }[\%]\end{array}$} \\
\hline & & sample & average & sample & average \\
\hline CU-0.1 & \multirow{8}{*}{$140 \times 180$} & 127.4 & \multirow{2}{*}{128} & - & \multirow{2}{*}{ - } \\
\hline CU-0.2 & & 128.6 & & - & \\
\hline CSL-1.3 & & 175 & \multirow{2}{*}{173.2} & 36.7 & \multirow{2}{*}{35.3} \\
\hline CSL-1.4 & & 171.4 & & 33.9 & \\
\hline CSL-1.5-0.3 & & 165.7 & \multirow{2}{*}{165.2} & 29.5 & \multirow{2}{*}{29.1} \\
\hline CSL-1.6-0.3 & & 164.7 & & 28.7 & \\
\hline CSL-1.7-0.5 & & 161.2 & \multirow{2}{*}{162.35} & 25.9 & \multirow{2}{*}{26.8} \\
\hline CSL-1.8-0.5 & & 163.5 & & 27.7 & \\
\hline
\end{tabular}

Table 3. Compressive force at concrete failure

Tabela 3. Siła ściskająca w chwili zniszczenia betonu

\begin{tabular}{|c|c|c|c|c|c|}
\hline \multirow[t]{2}{*}{ Sample } & \multirow{2}{*}{$\begin{array}{c}\text { Cross-section } \\
\text { dimensions } \\
b \times h[m m]\end{array}$} & \multicolumn{2}{|c|}{$\begin{array}{c}\text { Compressive force at } \\
\text { concrete failure (ULS) [kN] }\end{array}$} & \multicolumn{2}{|c|}{$\begin{array}{c}\text { Strengthening } \\
\text { effect [\%] }\end{array}$} \\
\hline & & sample & average & sample & average \\
\hline CU-0.1 & \multirow{8}{*}{$140 \times 180$} & 133.5 & \multirow{2}{*}{133.25} & - & \multirow{2}{*}{ - } \\
\hline CU-0.2 & & 133 & & - & \\
\hline CSL-1.3 & & 183.6 & \multirow{2}{*}{182.5} & 37.8 & \multirow{2}{*}{37.0} \\
\hline CSL-1.4 & & 181.4 & & 36.1 & \\
\hline CSL-1.5-0.3 & & 170.5 & \multirow{2}{*}{171.05} & 28.0 & \multirow{2}{*}{28.4} \\
\hline CSL-1.6-0.3 & & 171.6 & & 28.8 & \\
\hline CSL-1.7-0.5 & & 169.2 & \multirow{2}{*}{169.35} & 27.0 & \multirow{2}{*}{27.1} \\
\hline CSL-1.8-0.5 & & 169.5 & & 27.2 & \\
\hline
\end{tabular}


After strengthening of columns by CFRP laminates, the main steel reinforcement and the additional one work and redistribute the applied deformations among each other. When stress in steel reinforcement reach the yielding all additional tensile stress transfers to the laminate. Failure of the sample occurs after concrete crushing in the compressed edge of the column. In table 2 we compare the value of compressive loading when the strain in CFRP laminate corresponds to SLS.

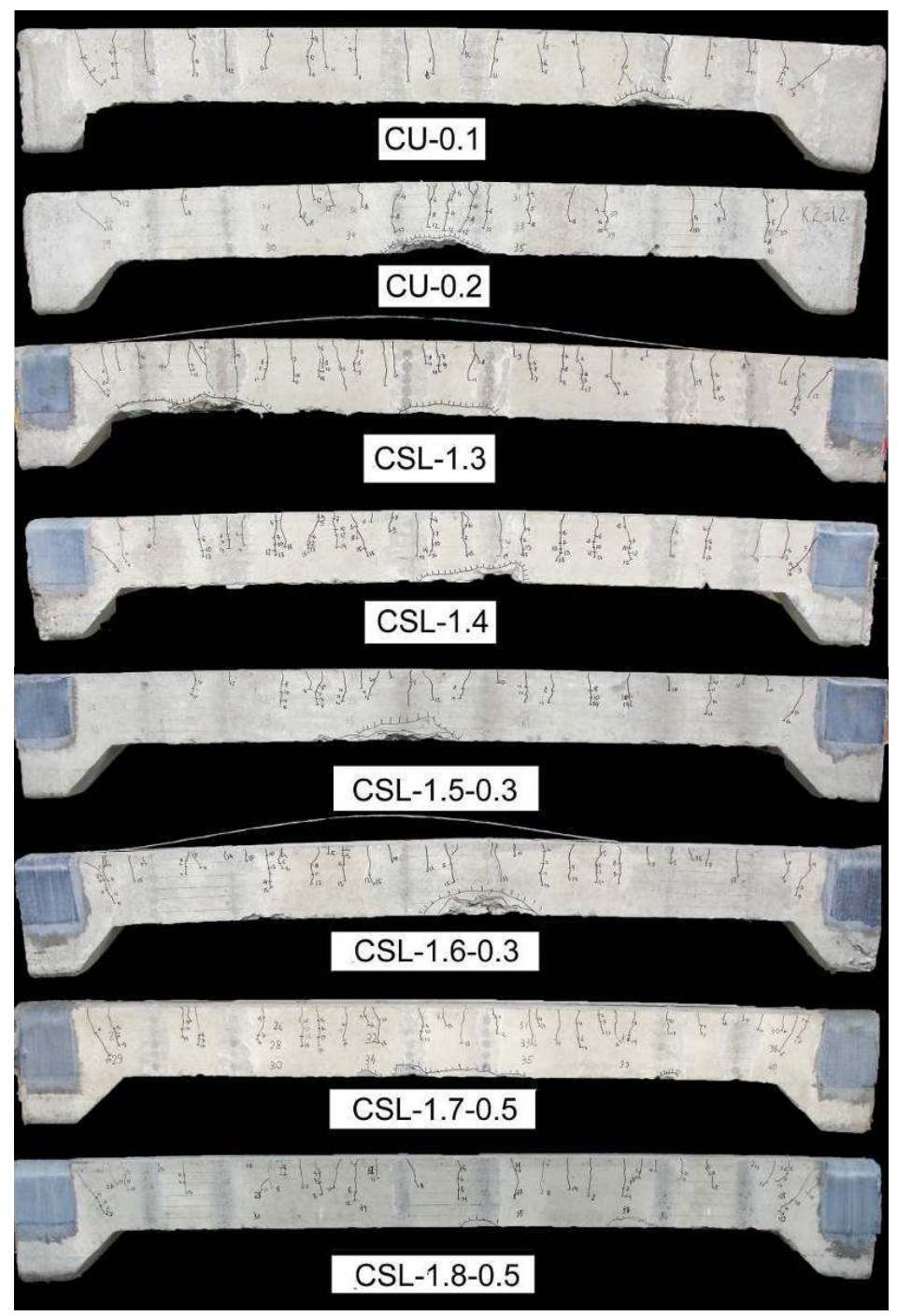

Fig. 5. Experimental columns after testing

Rys. 5. Widok próbek po badaniu 
According to tab. 2 the strengthening effect for samples CSL-1.3 and CSL1.4 was $35.3 \%$, for samples CSL-1.5-0.3 and CSL-1.6-0.3 - 29.1\% and for sample CSL-1.8-0.5 - 26.8\%. According to the norms FIB [6] the limit state corresponds to the load at which the strain in the steel or the CFRP laminate reaches the limit value. The limit deformation in the tape at all strengthened samples occurs at higher loading and therefore it corresponds to the limit state (SLS). Therefore, the effect of strengthening by SLS was from 26.8 to $35.3 \%$ depending on the loading level at the strengthening moment.

In table 3 the comparison of samples strength at moments of compressive concrete failure is presented. According to the norms FIB [6] it characterizes ultimate limit state (ULS). According to tab. 3 the strengthening effect for samples CSL-1.3 and CSL-1.4 was 37\%, for samples CSL-1.5-0.3 and CSL-1.6$-0.3-28.4 \%$ and for the sample CSL-1.8-0.5 - 27.1\%. Therefore the effect of strengthening by ULS was from 27,1 to $37,0 \%$ depending on the loading level at the strengthening moment. The scheme of the destruction of samples columns is shown in fig. 5.

It should be noted that in the sample of CSL-1.3 and CSL-1.5-0.3 there was debonding of the laminate at the site of anchoring (shown in fig. 5). How-ever, it happened after the destruction of the compressed area and the result of the sharp deformation growth. In other samples debonding was not observed. So we can conclude that the premature destruction of anchoring did not occur.

\section{Conclusion}

1. After experimental studies of reinforced concrete columns strengthened by CFRP laminate Sika CarboDur S512 there was determined that the laminate starts working with the main reinforcement immediately after application.

2. For evaluation of the strengthening effect of samples two types limit states were used. The first is ,serviceability limit state (SLS)", and the second - ,ultimate limit state (ULS)”. SLS corresponds to the moment when the strain in the stretched steel bars and CFRP laminate reaches the limit values. ULS corresponds to the moment when compressed concrete of cross-section is crushed.

3. The effect of strengthening by ULS was from 27,1 to $37,0 \%$ and by SLS was from 26.8 to $35.3 \%$ depending on the loading level at the strengthening moment. The effectiveness of strengthening increases with decreasing loading level on construction but this difference was small during testing.

\section{References}

[1] ACI 440.2R-08: Guide for the Design and Construction of Externally Bonded FRP Systems for Strengthening Concrete Structures. Published by American Concrete Institute, Farmington Hills, MI 2008. 
[2] ACI 440.3R: Guide Test Methods for Fiber-Reinforced Polymers (FRPs) for Reinforcing or Strengthening Concrete Structures. Published by the American Concrete Institute, Farmington Hills, 2004.

[3] Borisyuk O.P., Konopchuk O.: Calculation of bearing capacity of normal cross sections flexural reinforced concrete elements reinforced with external composite reinforcement for the actions of little cyclic loads. Recommendations - Rivne, NUVGP, 2012.

[4] Csuka B., Kollár L.P.: Analysis of FRP confined columns under eccentric loading. Composyte Structure, no 94 (3), pp. 1106-1116.

[5] DAfStb-Richtlinie Vorstand no 414: Verstärken von Betonbauteilen mit geklebter Bewehrung, Deutscher Ausschuss für Stahlbeton. Tiergarten, Berlin, Deutschland, November 2009.

[6] Design and use of externally bonded fibre reinforced polymer reinforcement for reinforced (FRP EBR) concrete structures, by 'EBR' working party of FIB TG 9.3, FIB Bulletin no 14, July 2001.

[7] Guide for the Design and Construction of Externally Bonded FRP Systems for Strengthening Existing Structures - Materials, RC and PC structures, masonry structures. CNR-DT 200/2004, Italian National Research Council, Rome, Italy 2004.

[8] Hadi M.N.S., Pham T.M., Lei X.: New method of strengthening reinforced concrete square columns by circularizing and wrapping with fiber-reinforced polymer or steel straps. Journal of Composites for Construction, no 17 (2), 2013, pp. 229-238.

[9] Kvasha V.G., Melnik I.V., Klimpush M.D.: Experimental research of reinforced concrete bridge beams for TP, vol. 56 reinforced composite tape of carbon fibers CFRP. Collection highways and road construction, Kiev 2001, pp. 267-271.

[10] Quiertant M., Clement J.-L.: Behavior of RC columns strengthened with different CFRP systems under eccentric loading. Construction and Building Materials, no 25 (2), 2011, pp. 452-460.

[11] Recommendation for Design and Construction of Concrete Structures Using Continuous Fibre Reinforcing Materials. Japan Society of Civil Engineers (JSCE). CLI31-1, Tokyo 1997.

[12] Recommendations for Upgrading of Concrete Structures with Use of Continuous Fibers Sheets. Japan Society of Civil Engineers (JSCE). Tokyo 2001.

[13] Retrofitting of concrete structures by externally bonded FRPs, with emphasis on seismic applications. FIB Bulletin no 35, 2006.

[14] Réparation et Renforcement des Structures en Béton Au Moyen des Matériaux Composites - Recommandations Provisoires. Bulletin Scientifique et Technique de l'AFGC. Association Française de Génie Civil, 2007.

[15] Rusinowski P., Täljsten B., Sand B.: Peeling failure at the cut-off end of CFRP strengthened rc beam"s. FRPRCS-9 Sydney, Australia 2009.

[16] SIA Norm 166, 2 Gesamtentwurf vom November 2001. Klebebewehrungen Schweizerischer Ingenieur- und Architektenverein, Postfach, CH-8039 Zürich 2001.

[17] Strengthened technology by composite materials, http://ukr.sika.com.

[18] Strengthening Reinforced Concrete Structures with Externally Bonded Fibre Reinforced Polymers. ISIS Design Manual no 4, Winnipeg, Canada 2001. 
[19] Technical Specification For Strengthening Concrete Structures with Carbon Fiber Reinforced Polymer Laminate, China Association for Engineering Construction Standardization (CECS 146). Beijing Planning Press, Beijing 2007.

[20] Trapko W., Trapko T.: Load-bearing capacity of compressed concrete elements subjected to repeated load strengthened with CFRP materials. Journal of Civil Engineering and Management, no 18 (4), 2012, pp. 590-599.

[21] TR55. Design Guidance for Strengthening Concrete Structures Using Fibre Composite Materials. The Concrete Society, UK 2004.

[22] TR57. Strengthening Concrete Structures With Fibre Composite Materials: Acceptance. Inspection And Monitoring, The Concrete Society, UK 2003.

[23] Yazici V., Hadi M.N.S.: Axial load-bending moment diagrams of carbon FRP wrapped hollow core reinforced concrete columns. J. Compos. Constr., no 13 (4), 2009, pp. 262-268.

\title{
WPLYW POZIOMU OBCIĄŻENIA KONSTRUKCJI NA NOŚNOŚĆ I ODKSZTAŁCALNOŚĆ ŻELBETOWYCH SŁUPÓW WZMOCNIONYCH TAŚMAMI CFRP
}

\begin{abstract}
Streszczenie
W pracy przedstawiono wyniki badań zbrojonych słupów żelbetowych wzmacnianych za pomocą taśm z włókien węglowych CFRP. Badania były prowadzone dla różnych poziomów obciążenia. Podczas użytkowania budynku bardzo trudno jest całkowicie odciążyć jego konstrukcję na czas remontu, a w niektórych przypadkach nawet niemożliwe. W symulacjach przyjęto współczynnik poziomu naprężeń przed wykonaniem wzmocnienia próbek badawczych dostosowanych do poziomu z 1/3 i 1/2 obciążenia niszczącego, ustalonego na podstawie badań słupów niepoddanych wzmocnieniu. W celu dokładniejszego porównania wyników badań dwa słupy zostały wzmocnione bez wstępnego obciążenia. Wszystkie próbki zostały wzmocnione przez taśmy z tworzywa o strukturze płytkowej CFRP Sika Carbodur S512 o szerokości taśmy $25 \mathrm{~mm}$. Obciążenie przyłożono mimośrodowo. Wartość mimośrodu dla wszystkich próbek $e=150 \mathrm{~mm}$. Przeprowadzona analiza porównawcza potwierdziła skuteczność stosowania wzmocnień elementów za pomocą taśm z włókien węglowych CFRP. Efektywność stosowania wzmocnień w postaci taśm z włókien węglowych wzrasta wraz ze zmniejszaniem się współczynnika poziomu naprężeń przed wykonaniem wzmocnienia konstrukcji. Jednak różnice te okazały się stosunkowo niewielkie.
\end{abstract}

Słowa kluczowe: słupy żelbetonowe, wzmocnienie, taśmy CFRP

Przestano do redakcji: 20.01.2014 $\mathrm{r}$.

Przyjęto do druku: 02.12.2014 r.

DOI: $10.7862 / \mathrm{rb} .2014 .131$ 